\title{
Evaluation of Major Ancestors of North American Soybean Cultivars for Resistance to Three Pythium Species that Cause Seedling Blight
}

K. S. Rod, Department of Crop Sciences, University of Illinois, Urbana 61801; D. R. Walker, ${ }^{\dagger}$ United States Department of AgricultureAgricultural Research Services and Department of Crop Sciences, University of Illinois, Urbana; and C. A. Bradley, Department of Plant Pathology, University of Kentucky Research and Education Center, Princeton 42445

\begin{abstract}
Pythium seedling blight, which can be caused by a number of Pythium spp., is a disease that affects soybean (Glycine max) in the United States and Canada. Pythium ultimum var. ultimum, one of the most common pathogenic species, is favored by cool, wet conditions in early spring and causes seed decay, root rot, and seedling damping-off. In all, 102 major ancestors of modern North American cultivars and "first progeny" cultivars developed directly from ancestral lines were evaluated for resistance to P. ultimum var. ultimum and two other species of Pythium in greenhouse assays. Several ancestors and first progeny cultivars, as well as the resistant check Archer, had varying levels of partial resistance to an Illinois isolate of $P$. ultimum var. ultimum. In a subsequent experiment,

four of the most resistant lines (PI 84637, Maple Isle, Fiskeby III, and Fiskeby 840-7-3) and the susceptible cultivar Kanro were screened for resistance against isolates of $P$. irregulare and $P$. sylvaticum, and resistance to $P$. ultimum var. ultimum was confirmed. The lines that were partially resistant to $P$. ultimum var. ultimum in the first experiment were also partially resistant to $P$. irregulare and $P$. sylvaticum. The $P$. ultimum var. ultimum isolate was the most aggressive of the three isolates, followed by the $P$. irregulare and $P$. sylvaticum isolates. Modern cultivars descended from the soybean lines with partial resistance to these pathogens could be useful sources of resistance to Pythium seedling blight if they are found to have similar levels of resistance.
\end{abstract}

Pythium seedling blight of soybean (Glycine max (L.) Merr.) can be caused by several different species of Pythium (Broders et al. 2007, 2009; Dorrance et al. 2004; Jiang et al. 2012; Rojas et al. 2017a). Pythium spp. are soilborne oomycetes that generally are most damaging when cool temperatures and rainfall follow planting (Broders et al. 2007; Dorrance et al. 2004). Symptoms caused by Pythium spp. that infect soybean include seed rot, preemergence seedling rot, root rot, and damping-off, which can result in poor emergence and sparse plant stands (Rothrock et al. 2015; Schlub and Lockwood 1981).

Pythium ultimum var. ultimum, $P$. irregulare, and $P$. sylvaticum are pathogenic on soybean and other field crops across U.S. soybean production regions (Broders et al. 2007, 2009; Brown and Kennedy 1965; Dorrance et al. 2004; Grau et al. 2004; Griffin 1990; Jiang et al.

${ }^{\dagger}$ Corresponding author: D. R. Walker; E-mail: david.walker@ars.usda.gov

Funding: Funding for a graduate research assistantship was provided by the United Soybean Board and the North Central Soybean Research Program and the research was supported, in part, by funding from the United States Department of Agriculture-Agricultural Research Services.

Mention of trade names or commercial products in this publication is solely for the purpose of providing specific information and does not imply recommendation or endorsement by the U.S. Department of Agriculture. The U.S. Department of Agriculture (USDA) prohibits discrimination in all its programs and activities on the basis of race, color, national origin, age, or disability, and where applicable, sex, marital status, familial status, parental status, religion, sexual orientation, genetic information, political beliefs, reprisal, or because all or part of an individual's income is derived from any public assistance program. (Not all prohibited bases apply to all programs.) Persons with disabilities who require alternative means for communication of program information (Braille, large print, audiotape, etc.) should contact USDA's TARGET Center at (202) 720-2600 (voice and TDD). To file a complaint of discrimination, write to USDA, Director, Office of Civil Rights, 1400 Independence Avenue, S.W., Washington, D.C. 20250-9410, or call (800) 795-3272 (voice) or (202) 720-6382 (TDD). The USDA is an equal opportunity provider and employer.

Accepted for publication 10 May 2018.

This article is in the public domain and not copyrightable. It may be freely reprinted with customary crediting of the source. The American Phytopathological Society, 2018.
2012; Rojas et al. 2017a; Rupe et al. 2011; Zhang and Yang 2000). P. ultimum var. ultimum grows best in temperatures of 5 to $35^{\circ} \mathrm{C}$, with temperatures below $23^{\circ} \mathrm{C}$ most favorable for infection. $P$. irregulare grows in temperatures between 1 and $35^{\circ} \mathrm{C}$, with $30^{\circ} \mathrm{C}$ being the optimal temperature, whereas $P$. sylvaticum grows optimally at $25^{\circ} \mathrm{C}$ but can grow at a minimum of $5^{\circ} \mathrm{C}$ to a maximum of 35 to $40^{\circ} \mathrm{C}$ (van der Plaats-Niterink 1981). P. ultimum was the most abundant of 29 Pythium spp. isolated from infected seedlings collected from 125 fields in North Dakota during 2011 and 2012, representing $21 \%$ of 2,675 isolates (Zitnick-Anderson and Nelson 2015). P. ultimum var. ultimum was also the most abundant species isolated from soybean fields in Ontario, Canada, in those same years, representing $56.7 \%$ of the isolates, followed by P. sylvaticum $(29.8 \%)$, in a survey conducted by Marchand et al. (2014). Of the two varieties of $P$. ultimum that are pathogenic on soybean in the United States, $P$. ultimum var. sporangiiferum is rarer than var. ultimum (Lévesque and De Cock 2004), though Jiang et al. (2012) recovered the same number of isolates of both in a survey conducted in Illinois. Lévesque and De Cock (2004) also found that based on internal transcribed spacer sequences, the two varieties of $P$. ultimum were in the I clade, whereas $P$. irregulare and $P$. sylvaticum were classified in the F clade of the genus Pythium. P. ultimum was also the third most abundant Pythium spp. that Kirkpatrick et al. (2006b) recovered from soybean plants from flooded fields in eastern Arkansas. Variation in the virulence and aggressiveness of $P$. ultimum isolates and populations has not been thoroughly investigated but available data indicate that variation exists and affects the expression of host resistance (Francis and St. Clair 1997).

The optimal planting date for maximizing soybean yield potential is 1 May in the U.S. Midwest (Robinson et al. 2009), and between mid-May and late May in Canada. Therefore, the trend of planting earlier in the growing season in northern production regions to maximize soybean yields ( $\mathrm{Hu}$ and Wiatrak 2012) is likely to increase Pythium-caused disease due to the higher likelihood of cool temperatures and abundant precipitation occurring (Broders et al. 2007; Rojas et al. 2017b). Management of diseases caused by Pythium spp. and other soilborne oomycetes requires a combination of improved soil drainage, tillage, crop rotation, resistant host plants, and fungicide seed treatments (Grau et al. 2004); however, the ability of $P$. ultimum var. ultimum to infect many of the field crops grown in the 
north-central United States and Canada reduces the efficacy of crop rotation.

Soybean resistance to Pythium spp. is uncommon but resistance to $P$. ultimum has been reported for the cultivars Archer, Dare, and Semmes and in the breeding line V81-141 (Bates et al. 2008; Griffin 1990; Keeling 1974; Kirkpatrick et al. 2006a). Archer was subsequently found to also be resistant to $P$. aphanidermatum, $P$. irregulare, and P. vexans (Bates et al. 2008; Rosso et al. 2008), and Semmes also has resistance to P. debaryanum (Keeling 1974). In a screening of 1,289 maturity group (MG) 000 to IV accessions from the United States Department of Agriculture (USDA) Soybean Germplasm Collection for resistance to P. ultimum in the field, Bernard et al. (1998) identified 60 accessions with resistance and another 52 that had heterogeneous reactions. Resistance of Plant Introduction (PI) 424354 to P. irregulare was discovered by Ellis et al. (2013). Although high levels of resistance to Pythium spp. have not been reported, it is possible that some modern North American cultivars inherited a moderate level of resistance from one or more of their ancestors; however, resistance to P. ultimum var. ultimum has not been thoroughly investigated.

On the basis of the pedigrees of 258 public soybean cultivars released in North America between 1947 and 1988, Gizlice et al. (1994) identified PI ancestors and "first progeny" from the USDA Soybean Germplasm Collection that constituted the genetic base of the North American public cultivars. The term "ancestor" referred to progenitors that had not been developed using manual hybridization, whereas the first progeny were lines and cultivars developed through manual hybridization, and for which no intermediates between them and at least one ancestor currently exist in the USDA Soybean Germplasm Collection. Gizlice et al. (1994) estimated that 91 first progeny constituted more than $99 \%$ of the North American soybean genetic base. These consisted of 5 breeding lines, 8 older cultivars, and 78 modern cultivars. The 91 first progeny lines have been evaluated for resistance to several soybean pathogens, including Macrophomina phaseolina (Pawlowski et al. 2015), Fusarium virguliforme (Mueller et al. 2003), Rhizoctonia solani (Bradley et al. 2001), and multiple soybean viruses (Wang et al. 2005).

The objectives of this study were to test soybean germplasm accessions that Gizlice et al. (1994) identified as the genetic base of North American soybean cultivars for resistance to P. ultimum var. ultimum, and to determine whether any lines with resistance to $P$. ultimum var. ultimum are also resistant to other pathogenic species of Pythium.

\section{Materials and Methods}

Inoculum production. Isolate $12 \mathrm{Py} 391$ of $P$. ultimum var. ultimum, originally collected in 2012 from a soybean field in Fayette County, IL, was used in the assays. In a preliminary experiment conducted to compare the aggressiveness of six different $P$. ultimum var. ultimum isolates on soybean seedlings, $12 \mathrm{Py} 391$ was determined to be the most aggressive (data not shown). To prepare inoculum, millet (Panicum miliaceum) seed were soaked for $12 \mathrm{~h}$ in tap water and drained. The millet seed were then autoclaved at $121^{\circ} \mathrm{C}$ for $60 \mathrm{~min}$ in an autoclavable bag ( 89 by $63.5 \mathrm{~cm}$ ), allowed to cool to room temperature, then autoclaved a second time for $60 \mathrm{~min}$. Once cooled to room temperature, two 5-day-old cultures of P. ultimum var. ultimum isolate 12Py391 grown on potato dextrose agar in 89-mm-diameter Petri dishes were added to each bag of autoclaved millet seed. The inoculated millet seed were incubated for 1 week at room temperature ( 21 to $25^{\circ} \mathrm{C}$ ) to allow the pathogen to colonize the seed, and the bags were gently massaged at day 4 to evenly distribute the colonized seed in the bag. The inoculum was then dried with forced air at $25^{\circ} \mathrm{C}$ for 2 days and ground using a Model 60GM Grinding Mills grinder (The C.S. Bell Co., Tiffin, $\mathrm{OH}$ ) to ensure that the inoculum was a uniform size (1 to $2 \mathrm{~mm}$ in diameter).

Evaluation of North American ancestral soybean lines for resistance to $\boldsymbol{P}$. ultimum var. ultimum. In all, 102 germplasm accessions from the USDA Soybean Germplasm Collection were screened for resistance to the 12Py391 isolate in the first experiment (Table 1).
These included 90 of the North American ancestral lines identified by Gizlice et al. (1994), with 58 ancestors and 32 first progeny. These will be referred to collectively as "ancestral lines". Archer and 10 of its progenitors were also tested, as well as two cultivars known to be susceptible to Pythium spp., Jack and Sloan (Dorrance et al. 2004; Ellis et al. 2013). The cultivar Sioux was not included in the screening because seed were not available (McLachlan 2016). Seed were obtained from the USDA Soybean Germplasm Collection in Urbana, IL. Archer, an MG I cultivar, was included because of its resistance to Arkansas isolates of several Pythium spp., including $P$. ultimum, $P$. aphanidermatum, and $P$. irregulare (Bates et al. 2008; Rosso et al. 2008; Urrea et al. 2017). The 10 ancestors of Archer were chosen on the basis of pedigree information available at the SoyBase (https://soybase.org/uniformtrial) and Germplasm Resources Information Network (https://www. ars-grin.gov/) websites.

Ten seeds of the same soybean genotype were planted in plastic pots (approximately $15 \mathrm{~cm}$ in diameter) that contained 1.6 liters of steam-pasteurized soil of a sandy loam mix (two parts torpedo sand and one part soil). Prior to planting, $5 \mathrm{~g}$ of P. ultimum var. ultimum inoculum (described above) was uniformly spread in a layer $5 \mathrm{~cm}$ below the soil surface and $2.5 \mathrm{~cm}$ below the seed. Each pot served as an experimental unit, with three replications of each soybean line tested. A noninoculated control pot also was included to confirm the seed viability for each soybean line but was not replicated. Pots were arranged in a completely randomized design, and the experiment was repeated once. Greenhouse temperatures ranged from $21^{\circ} \mathrm{C}$ in the daytime to $16^{\circ} \mathrm{C}$ at night. No artificial lighting was used, and the natural photoperiod during the experiment was approximately $14 \mathrm{~h}$. Plants were watered until the soil was moist once each day. The layer-inoculation technique used and the method used to prepare the inoculum were modifications of methods described by Kirkpatrick et al. (2006a) and Mueller et al. (2003), and were described in greater detail by McLachlan (2016).

Two weeks after planting, data were collected for plant stand per pot, shoot dry weight per plant, and root dry weight per plant. Plant stand was measured as the number of plants per pot that emerged from the soil. Soil was washed away from the roots of the plants, and the stems were cut with scissors at the soil line. Shoots and roots were dried with forced air at $25^{\circ} \mathrm{C}$ for 3 days before being weighed. Total weights of the roots and shoots from each pot were divided by the plant stand number to calculate the mean root or shoot dry weight per plant.

Evaluation of selected soybean lines for reactions to two other Pythium spp. Four soybean lines that showed varying levels of partial resistance to $P$. ultimum var. ultimum in the ancestral genotype screen were subsequently screened with isolates of $P$. irregulare and $P$. sylvaticum, in addition to the $P$. ultimum var. ultimum $12 \mathrm{Py} 391$ isolate that was used in the ancestral line screen. Kanro, a line that was susceptible to the $12 \mathrm{Py} 391$ isolate in the previous experiment, was also included in the assay as a susceptible check. The $P$. irregulare isolate, $12 \mathrm{Py} 354$, was collected from a soybean field in Gallatin County, IL in 2012, and P. sylvaticum isolate $12 \mathrm{Py} 353$ was collected from a soybean field in Fayette County, IL in 2012. All three Pythium spp. have been reported to be pathogenic on soybean (Broders et al. 2007, 2009; Jiang et al. 2012; Rojas et al. 2017a).

PI 84637, Maple Isle, and Fiskeby III were included because they had some of the highest relative plant stands and relative shoot and root dry weights compared with their noninoculated controls after being challenged with $P$. ultimum var. ultimum in the previous ancestral soybean screening experiment. Fiskeby 840-7-3, also known as Holmberg 840-7-3, was chosen to represent a moderately resistant line because it was close to the median of the cultivars that were significantly different from the ratings of the most susceptible lines. All four of the resistant lines were in MG II or an earlier MG. Kanro (PI 548356) was used as the susceptible check because it was highly susceptible in the previous experiment and because it is also in MG II.

This factorial experiment was conducted as a completely randomized design, with three Pythium spp. and five soybean lines. Each 
species-soybean line combination had six inoculated replications and one noninoculated control. The experiment was repeated once, and the experimental conditions and methods were the same as described previously. After 2 weeks of growth, data for plant stand per pot, shoot dry weight per pot, and root dry weight per pot were collected. Shoots and roots of inoculated replications and the noninoculated controls were dried on a whole-pot basis. The weight of tissue per pot was divided by the number of plants to calculate mean weight per plant (McLachlan 2016).

Statistical analyses. Data were analyzed using SAS (version 9.4; SAS Institute Inc., Cary, NC). Plant stands from inoculated pots were compared with their noninoculated controls and expressed as a percentage relative to those. The average weight per plant of the shoot or root was then compared with the average weight per plant part of the noninoculated control, and was expressed as a percentage relative to the corresponding control. In all replicated experiments, analysis of variance was conducted using the mixed-model procedure (PROC MIXED). For each repeated experiment, the data from each experiment were pooled and analyzed together because there was no significant $(P \leq 0.05)$ soybean line-experiment interaction. Cultivar (i.e., genotype) was considered a fixed variable and experiment was considered random. Relative means from the lines in the ancestral screen were tested for significant differences using Fisher's protected least significant difference (LSD) test at $\alpha=0.05$ with the PDMIX800 macro (Saxton 1998). Correlations between plant stand, root weight, and shoot weight were tested with the Spearman's Rank Correlation (PROC CORR). In the soybean line-Pythium spp. experiment, the pathogen-soybean line interaction was significant $(P \leq$ $0.05)$; therefore, relative means from the species and soybean lines were compared using Fisher's protected LSD with the PDMIX800 macro. Correlations between plant stand, root weight, and shoot weight were tested using the Spearman's Rank Correlation as well.

\section{Results}

Evaluation of ancestral soybean lines for resistance to $P$. ultimum var. ultimum. Significant differences among the soybean lines were found for plant stand $(P<0.0001)$, root dry weight $(P<$ $0.0001)$, and shoot dry weight $(P<0.0001)$ ratios for inoculated plants relative to those of noninoculated plants. The 12Py391 isolate had a detrimental effect on seedling emergence of all of the lines, including the partially resistant check Archer (Fig. 1). Plant stands ranged from 0 to $58 \%$ of the noninoculated controls, with an LSD of 0.18 (Table 2). Forty-five lines had plant stands that were less than $10 \%$ of their noninoculated controls, illustrating the aggressiveness of the isolate used. Root dry weights ranged from 0 to $93 \%$ of noninoculated controls, and shoot dry weights ranged from 0 to $94 \%$ (Table 2). Considerable variation among plants within inoculated treatments resulted in LSDs of 0.43 and 0.44 for root and shoot dry weights, respectively; therefore, those data were considered to be less informative measurements of resistance and susceptibility than plant stand ratios.

Out of the 102 accessions evaluated in the ancestral lines experiment, only 4 lines (Harosoy, Maple Isle, Delmar, and PI 84637) had significantly higher plant stands than both Jack and Savoy, the susceptible controls (Table 2; Fig. 1). PI 84637 also had the highest root dry weight compared with its noninoculated control (0.93), and Harosoy was the only line among the other three lines that had a root dry weight significantly lower than that of PI 84637. The shoot dry weight ratios of all four lines were also not significantly lower than those of Fiskeby III (0.94) or Jogun (0.94), the lines with the highest weights relative to their noninoculated controls. PI 84637 was the only one of the four lines that is not a cultivar developed in North America, and Delmar was the only one from an MG higher than II (Table 1).

Plant stand ratios in the inoculated pots of Habaro (0.41), Chico (0.40), Hodgson (0.38), PI 54615-1 (0.37), Fiskeby III (0.37), and Richland (0.37) were significantly higher than that of Jack (0.19) but not Sloan (Table 2). The root and shoot dry weight ratios for all of these were also relatively high; thus, it is possible that they have some resistance to the isolate used. All five of these accessions are in MG II or a lower MG. Chico and Hodgson are cultivars from
Minnesota; Habaro, PI 54615-1, and Richland are germplasm accessions from East Asia; and Fiskeby III is a cultivar that was developed in Sweden.

The Spearman rank correlation showed that plant stand was positively correlated with both root dry weight $(P<0.0001)$ and shoot dry weight $(P<0.0001)$, and that root dry weight was positively correlated with shoot dry weight $(P<0.0001)$ (Table 3$)$. Despite this overall trend, several lines with some of the highest root and shoot dry weights had comparatively poor seedling emergence. For example, Jogun (PI 548352) had the highest relative shoot dry weight ratio $(0.95)$ and a relatively high root weight ratio $(0.71)$ but inoculated pots had a low plant stand relative to noninoculated pots (0.23). A similar discrepancy between poor plant stands and relatively high dry weight ratios was also observed for Mejiro (PI 80837), Novosadska Bela (PI 248404), Fiskeby 840-7-3 (PI 438477), Aoda (PI 548301), and T204 (PI 548195), as well as for Archer, the check with putative partial resistance (Table 2). PI 54615-1 is in MG III and Aoda is in MG IV but the other lines are from earlier MG.

Relative to its progenitors, inoculated Archer plants had numerically higher root and shoot weights than Adams (PI 548502), and a numerically higher plant stand than Adams, Amsoy (PI 548506), BSR-101 (PI 548519), and Clark (PI 548533) (Table 2). Harosoy had a higher relative plant stand than Archer and similar root and shoot dry weights; thus, it would be a good candidate for the source of Archer's resistance to Pythium spp. Blackhawk was not among the lines with the most resistance to the $P$. ultimum var. ultimum isolate used in this study, even though it is derived from Richland (Cober and Voldeng 2012) and is in the pedigree of Archer.

Reactions of four partially resistant ancestral lines to three Pythium spp. Interactions between the five selected soybean lines and the three Pythium spp. were significant for plant stands $(P<$ $0.0001)$, root dry weights $(P<0.0001)$, and shoot dry weights $(P<$ $0.0001)$ of inoculated treatments relative to noninoculated treatments. PI 84637, Maple Isle, Fiskeby III, and Fiskeby 840-7-3 were all partially resistant to the isolates of $P$. ultimum var. ultimum, $P$. irregulare, and $P$. sylvaticum used, thus confirming that these four lines are partially resistant to the $12 \mathrm{Py} 391$ isolate. Plant stand was again positively correlated with shoot and root dry weights (Table 4), which were also positively correlated with one another.

The isolates of the three Pythium spp. used in the screen varied in aggressiveness toward the four partially resistant soybean lines challenged in this experiment. The P. ultimum var. ultimum $12 \mathrm{Py} 391$ isolate was the most aggressive, causing, on average, a $33 \%$ reduction in plant stand, a $46 \%$ reduction in mean root weight, and a $24 \%$ reduction in shoot weight (Table 5). The $P$. irregulare isolate was the second most aggressive isolate, causing, on average, a $22 \%$ reduction in relative mean plant stand, a $33 \%$ reduction in root weights, and a $26 \%$ reduction in shoot weights (Table 5). The $P$. sylvaticum isolate was the least aggressive of the three isolates, failing to reduce any of the measured disease reaction parameters by more than $7 \%$ (Table 5). The relative plant stand and shoot weight means for the susceptible soybean line Kanro were significantly lower than those of the partially resistant lines inoculated with the P. ultimum var. ultimum isolate. The relative mean plant stand of Kanro was also significantly lower than the stands of the partially resistant lines inoculated with the $P$. irregulare isolate. In contrast, when Kanro plants were challenged with the $P$. sylvaticum isolate, the mean stand counts and the root and shoot dry weights were above 0.90 relative to the noninoculated control.

\section{Discussion}

Despite the abundance of Pythium pathogens of soybean, resistance to Pythium spp. has received much less attention than Phytophthora sojae resistance in both research efforts and soybean breeding programs (Rojas et al. 2017b). To our knowledge, this is the first study to specifically evaluate the major ancestors of North American soybean cultivars for resistance to Pythium ultimum var. ultimum and other Pythium spp. The foreign germplasm accessions and first progeny cultivars that Gizlice et al. (1994) identified as the genetic foundation of North American soybean breeding prior to 1989 served 
as a logical starting point for investigating sources of Pythium resistance. However, a few points about the Gizlice et al. (1994) study should be borne in mind,. One is that it was conducted more than two decades before the present study, and at a time when cultivars from private companies were just beginning to dominate soybean seed sales in the United States. Because the pedigrees of proprietary cultivars are seldom divulged, it is not possible to estimate the extent to which the findings of Gizlice et al. (1994) apply to currently grown cultivars. Another point to keep in mind is that some of the cultivars in the Gizlice et al. (1994) pedigree analyses were relatively recent releases at the time that study was conducted; thus, their genetic contribution to cultivars released after 1988 may have been substantially greater than it had been to pre-1989 cultivars. This is particularly true for cultivars bred for Canada, where soybean production underwent very rapid expansion between 1971 and 2000 (Cober and Voldeng 2012).

Bernard et al. (1998) had previously screened 656 germplasm accessions from MG 000 to IV for resistance to $P$. ultimum in a 1964 field test, and another 633 accessions were screened in 1965 and 1966. Those assays were limited to accessions with PI numbers of 266807 or lower that had been acquired by the USDA Soybean Germplasm Collection before 1961. Fewer than 5\% of the 1,289 accessions screened were rated as resistant to $P$. ultimum, and the reactions of another $4 \%$ were heterogeneous (https://www.ars-grin.gov/). A large percentage of the resistant accessions originated from either northeast China, the Korean peninsula, or northern Japan.

Table 1. Ancestral and first progeny lines, the cultivar Archer, and ancestors of Archer assayed for their reactions to an Illinois isolate of Pythium ultimum var. ultimum

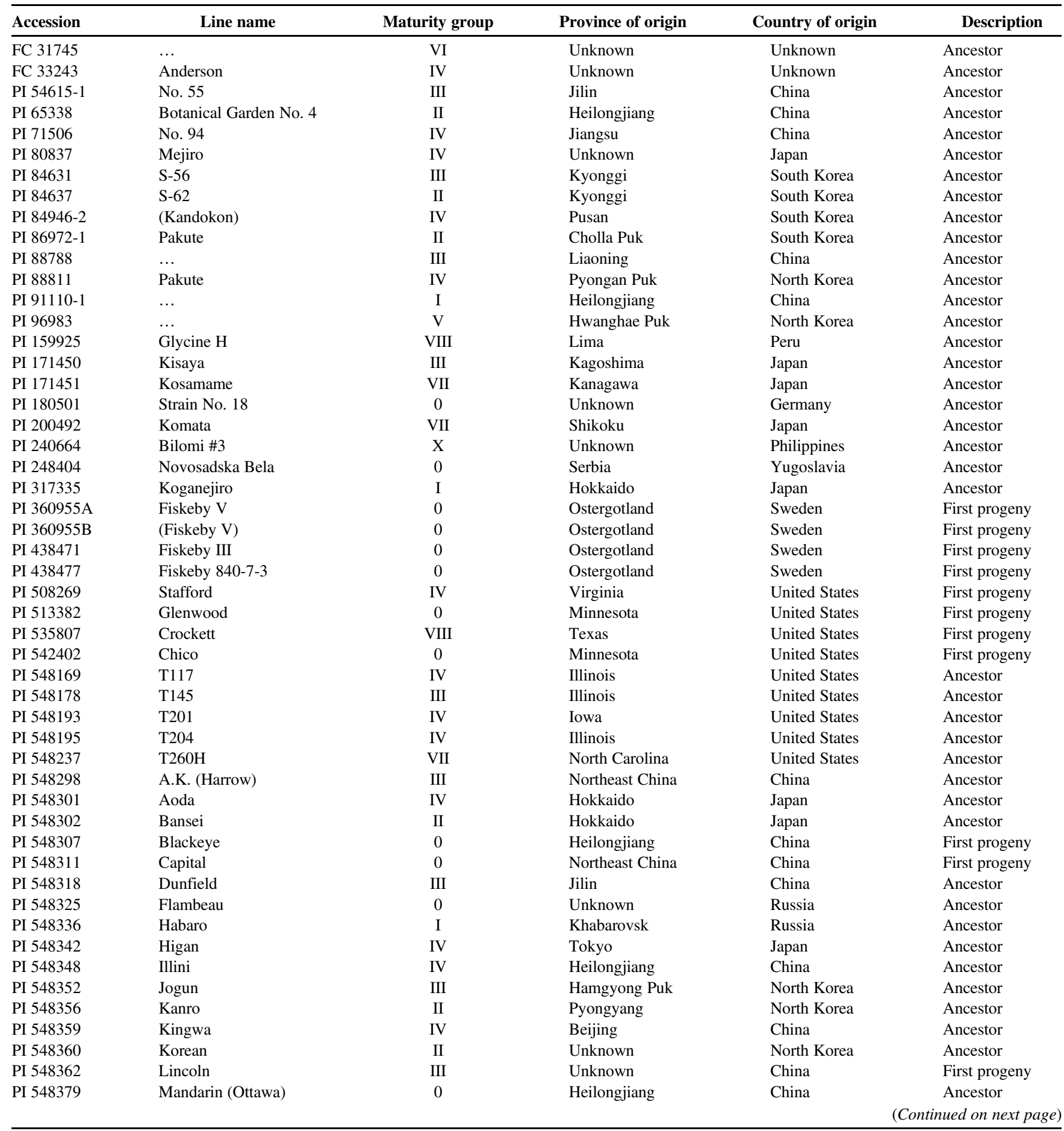


Surprisingly, PI 86437 (Line S-62), which had among the highest levels of resistance to the P. ultimum var. ultimum isolate used in our study, had been rated as susceptible to $P$. ultimum in the 1964 field evaluations. Bernard et al. (1998) did not provide many details about the methods used to determine and rate reactions to $P$. ultimum in their field tests but it seems unlikely that $P$. ultimum would have been the only soybean pathogen in the soil, and the presence of other pathogenic soil organisms could have affected apparent $P$. ultimum resistance. Although it is also possible that the $P$. ultimum pathotypes in the field where the Bernard et al. (1998) screening was conducted were different from the 12Py391 isolate used in our assays, the 12Py391 isolate was chosen because it was more aggressive than other P. ultimum var. ultimum isolates that we tested. The lack of any seedling emergence from 16 lines in the inoculated treatment demonstrated the aggressiveness of this Illinois isolate.
The ancestral lines and first progeny that appeared to have resistance to the 12Py391 isolate can be classified into three groups. Lines in the first group had plant stand ratios significantly higher than those of both Sloan and Jack (susceptible controls), whereas the ratios of the lines in the second group were only significantly higher than that of Jack. A third group consisted of lines with relatively low plant stand ratios but whose surviving plants had high root and shoot dry weights compared with noninoculated plants. Further investigations are needed to determine whether the third group has a different mode of resistance that is more effective postemergence than preemergence. We are relatively confident in concluding that the lines in the first group are truly resistant but believe that resistance of lines in the second and third groups needs to be confirmed.

Of the four lines with plant stand ratios significantly higher than those of both Sloan and Jack, Harosoy and Maple Isle had the highest

Table 1. (Continued from previous page)

\begin{tabular}{|c|c|c|c|c|c|}
\hline Accession & Line name & Maturity group & Province of origin & Country of origin & Description \\
\hline PI 548382 & Manitoba Brown & 0 & Unknown & Unknown & Ancestor \\
\hline PI 548383 & Mansoy & III & Heilongjiang & China & Ancestor \\
\hline PI 548391 & Mukden & IV & Liaoning & China & Ancestor \\
\hline PI 548402 & Peking & III & Beijing & China & Ancestor \\
\hline PI 548406 & Richland & II & Jilin & China & Ancestor \\
\hline PI 548409 & Sato & IV & Hokkaido & Japan & Ancestor \\
\hline PI 548411 & Seneca & II & Northeast China & China & Ancestor \\
\hline PI 548438 & Arksoy & VI & Pyongyang & North Korea & Ancestor \\
\hline PI 548444 & Biloxi & VIII & Zhejiang & China & Ancestor \\
\hline PI 548445 & CNS & IX & Jiangsu & China & Ancestor \\
\hline PI 548456 & Haberlandt & $\mathrm{V}$ & Pyongyang & North Korea & Ancestor \\
\hline PI 548457 & Hahto & VI & Fukushima & Japan & Ancestor \\
\hline PI 548461 & Improved Pelican & VIII & Unknown & China & First progeny \\
\hline PI 548463 & Laredo & IV & Shaanxi & China & Ancestor \\
\hline PI 548469 & Mammoth Yellow & VII & Unknown & Japan & Ancestor \\
\hline PI 548477 & Ogden & VI & Unknown & Unknown & First progeny \\
\hline PI 548484 & Ralsoy & VI & Pyongyang & North Korea & Ancestor \\
\hline PI 548485 & Roanoke & VII & Jiangsu & China & Ancestor \\
\hline PI 548488 & S-100 & $\mathrm{V}$ & Heilongjiang & China & Ancestor \\
\hline PI 548493 & Tokyo & III & Kanagawa & Japan & Ancestor \\
\hline PI 548494 & Volstate & VII & Unknown & Unknown & First progeny \\
\hline PI 548528 & Protana & II & Indiana & United States & First progeny \\
\hline PI 548548 & Delmar & IV & Delaware & United States & First progeny \\
\hline PI 548559 & Emerald & IV & Delaware & United States & First progeny \\
\hline PI 548561 & Hodgson & I & Minnesota & United States & First progeny \\
\hline PI 548587 & Kim & III & Iowa & United States & First progeny \\
\hline PI 548595 & Maple Isle & 0 & Ontario & Canada & First progeny \\
\hline PI 548599 & Monroe & I & Ohio & United States & First progeny \\
\hline PI 548603 & Perry & IV & Indiana & United States & First progeny \\
\hline PI 548604 & Pershing & IV & Missouri & United States & First progeny \\
\hline PI 548623 & Vansoy & 0 & Ontario & Canada & First progeny \\
\hline PI 548626 & Wabash & IV & Indiana & United States & First progeny \\
\hline PI 548633 & Wye & IV & Maryland & United States & First progeny \\
\hline PI 548657 & Jackson & VII & North Carolina & United States & First progeny \\
\hline PI 548663 & Dowling & VIII & Texas & United States & First progeny \\
\hline PI 548697 & Majos & VIII & South Carolina & United States & First progeny \\
\hline PI 548983 & Tracy & VI & Mississippi & United States & First progeny \\
\hline PI 553048 & Vance & $\mathrm{V}$ & Virginia & United States & First progeny \\
\hline PI 567790 & Curtis & VI & Louisiana & United States & First progeny \\
\hline PI 546487 & Archer & I & Iowa & United States & Resistant check \\
\hline PI 548519 & BSR-101 & I & Iowa & United States & Archer pedigree \\
\hline PI 548506 & Amsoy & II & Iowa & United States & Archer pedigree \\
\hline PI 548527 & Calland & III & Indiana & United States & Archer pedigree \\
\hline PI 548502 & Adams & III & Iowa & United States & Archer pedigree \\
\hline PI 548573 & Harosoy & II & Ontario & Canada & Archer pedigree \\
\hline PI 548504 & Altona & 0 & Manitoba & Canada & Archer pedigree \\
\hline PI 548516 & Blackhawk & I & Iowa & United States & Archer pedigree \\
\hline PI 548533 & Clark & IV & Illinois & United States & Archer pedigree \\
\hline PI 518671 & Williams 82 & III & Illinois & United States & Archer pedigree \\
\hline PI 540556 & Jack & II & Illinois & United States & Susceptible check \\
\hline PI 548616 & Sloan & II & Iowa & United States & Susceptible check \\
\hline
\end{tabular}


survival rates in inoculated pots. This is interesting because Harosoy (MG II) is an ancestor of Maple Isle (MG 0) (Cober and Voldeng 2012; Voldeng et al. 1985). Maple Isle originated as a selection from a single backcross of Harosoy e3 to PI 194641. Because Harosoy e3 is an early-maturing isoline of Harosoy (Bernard et al. 1988; Voldeng et al. 1985), it is conceivable that Maple Isle could have inherited resistance to $P$. ultimum var. ultimum from Harosoy, which we tested in our study because it is also an ancestor of Archer (Cianzio et al. 1991). Although Archer was not among the most resistant lines to the $12 \mathrm{Py} 391$ isolate, it is partially resistant to other pathogenic species and isolates of Pythium (Bates et al. 2008). Harosoy was selected from a backcross between Mandarin (Ottawa) and a line derived from a cross between Mandarin (Ottawa) and A.K. (Harrow). Surprisingly, neither of these ancestral lines exhibited any resistance to the 12Py391 isolate in this study; therefore, the source of Pythium resistance in Harosoy is a mystery unless some combination of minor resistance genes inherited from both of its parents was effective when combined in the genetic background of Harosoy. Chico, an MG 00 cultivar from Minnesota that appeared to have some resistance in our assays, also has Harosoy in its pedigree, by way of both Evans and Corsoy (Orf et al. 1985). Evans was also a parent of the first progeny cultivar Glenwood, which was not resistant to the 12Py391 isolate (Table 2).

PI 84637 was obtained by the U.S. National Plant Germplasm System in 1929 from the Suigen Experiment Station in Gyonggido (Kyonggi) province, which surrounds Seoul in the northwestern corner of what is now the Republic of Korea (https://www.ars-grin. gov/). It is not clear, however, whether this MG II accession is originally from that region, because W. J. Morse, one of the two collectors from the USDA Bureau of Plant Industry, wrote in 1930 that Korean, Japanese, and Manchurian varieties were being evaluated at the Suigen station (Shurtleff and Aoyagi 2017). Morse also reported that hybridization, as well as selection to purify lines, was being used in Suigen at that time. The assignment of the Suigen AES number S-62 to PI 84637 suggests that, whatever the origin of this line, it had been selected for its performance in that region of the Korean peninsula. According to information at the Germplasm Resource Information Network website (https://www.ars-grin.gov/), PI 84637 was rated as susceptible to $P$. ultimum in 1964 field tests conducted by Bernard et al. (1998). It is interesting to note, however, that at least 13 other soybean accessions that had been collected in Gyonggi or Seoul at the same time as PI 84637 had either resistant or heterogeneous reactions to $P$. ultimum in field assays that Bernard et al. (1998) conducted in 1965 and 1966. PI 424354, a line that Ellis et al. (2013) reported to have resistance to a $P$. irregulare isolate, originates from Chungcheongnam province, which lies immediately to the south of Gyonggi province. Because PI 424354 was not considered by Gizlice et al. (1994) to be one of the North American ancestral lines, it was not evaluated in the present study.

The last of the four lines with the highest plant stand ratios was the first progeny Delmar, an MG IV cultivar released by the University of Delaware in 1967. This line differed from the other three in being

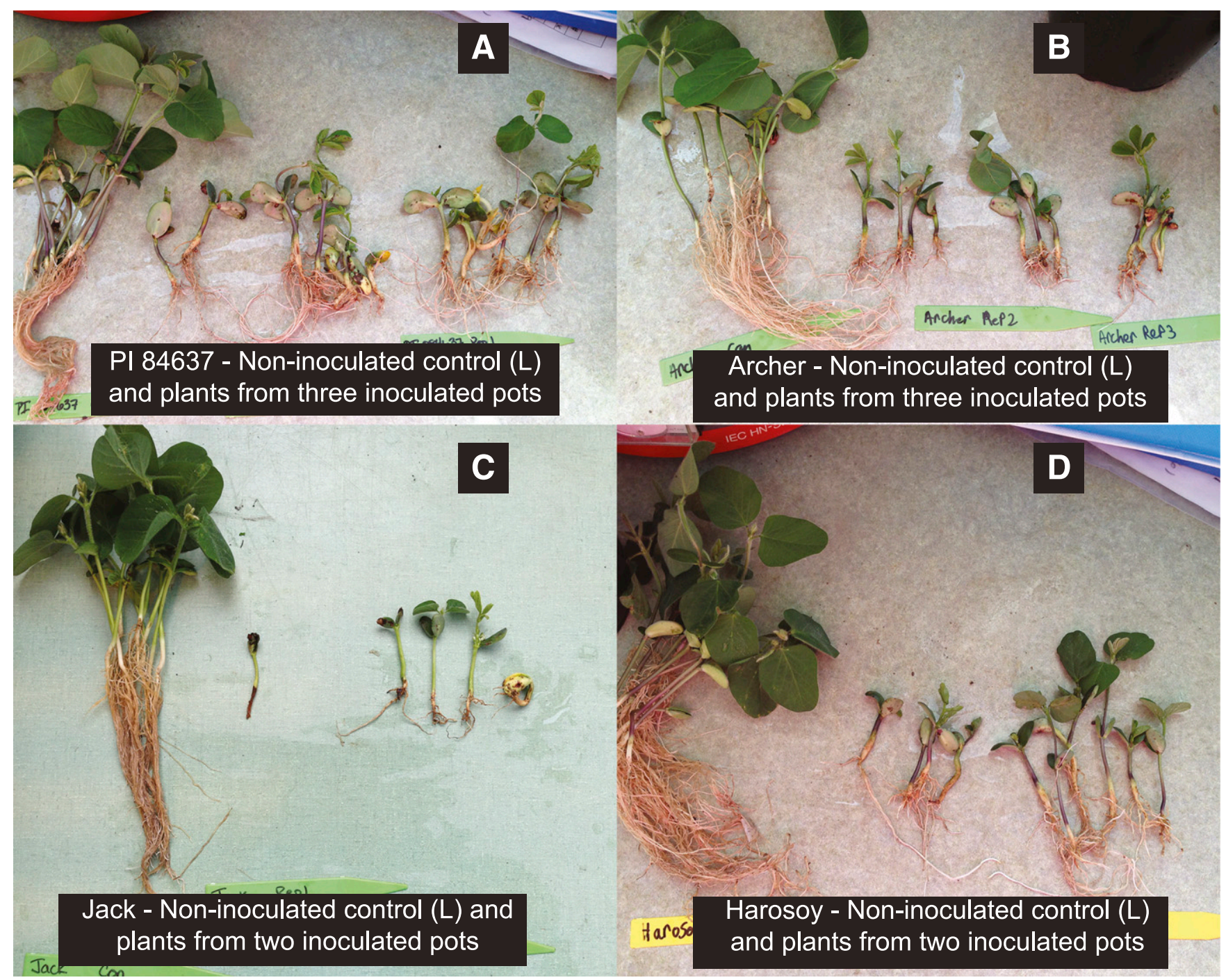

Fig. 1. Symptoms of Pythium seedling blight on A, the North American soybean ancestral line PI 84637; B, the partially resistant check Archer; C, the susceptible check Jack; and D, Harosoy. All genotypes were inoculated with the 12Py391 isolate of Pythium ultimum var. ultimum from Illinois. 
from a later MG and in being adapted to a lower latitude. It was derived from the cross C $799 \times$ F. C. 33243 (Crittenden and Cole 1967). The pedigrees of the parents were not described in the release but the maternal parent was presumably a breeding line, and the paternal parent was apparently an off-type MG IV plant selected from a field of Lincoln in 1954 (https://www.ars-grin.gov/). Lincoln was developed in Illinois from a cross between Mandarin and Manchu, two accessions from Heilongiiang Province in northeastern China, where several other ancestral lines tested in this study had also been collected. Neither Mandarin nor Manchu were in this study but Mandarin (Ottawa), an earlier-maturing selection from Mandarin, was not resistant to the 12Py391 isolate. As mentioned earlier, Mandarin (Ottawa) is an ancestor of Harosoy and, therefore, a progenitor of many Canadian cultivars (Cober and Voldeng 2012). Considering that all of the most resistant ancestors and first progeny except Delmar are in lower MG, it is possible that the resistance genes in Delmar were inherited from one or more ancestors from northern China.

Of the lines that had plant stand ratios significantly greater than Jack but not greater than Sloan, Chico (late MG 00) was previously mentioned for having two Harosoy-derived lines in its pedigree (Orf et al. 1985). Richland, another ancestral line with putative resistance to the 12Py391 isolate, was the variety name given to an MG II line descended from a 1927 selection from PI 70502 (https://www.arsgrin.gov/). PI 70502 was collected in China's Jilin province, which borders present-day North Korea. Like Chico, the MG I cultivar Hodgson was developed and selected in Minnesota, and also has the Harosoy-derived cultivar Corsoy in its pedigree (Lambert and Kennedy 1975). Hodgson also has Lincoln and Richland in its pedigree, as well as PI 180501, an accession originally from Manchuria that had been selected in Germany.

Ancestral lines that had high root and shoot dry weight ratios but relatively low plant stand ratios included Mejiro (PI 80837), Fiskeby III, Fiskeby 840-7-3, T204 (PI 548195), Aoda (PI 548301), Jogun (PI 548352), and Richland. The putative resistance of these lines needs to be confirmed. Fiskeby 840-7-3, Fiskeby III, Mejiro, and Jogun each contributed less than $1 \%$ to the total genes in pre-1989 cultivars but Richland had contributed $8.2 \%$ of the genes to public cultivars overall and $11.3 \%$ to the northern gene pool (Gizlice et al. 1994). With the major expansion of soybean production in Ontario and in the north-central states of the United States since the 1980s, however, it is likely that the relative contributions of early-maturing lines such as Fiskeby 840-7-3 and Fiskeby III to modern cultivars with earlier maturities is higher. Mejiro, Aoda, and T204 are in MG IV, while the other lines were in earlier MG.

The results of the experiment in which four resistant lines and one susceptible line were inoculated with isolates of $P$. ultimum var. ultimum, P. irregulare, and P. sylvaticum confirmed that PI 84637, Maple Isle, Fiskeby III, and Fiskeby $840-7-3$ are resistant to the 12Py391 isolate of P. ultimum var. ultimum (Table 5), and showed that these four lines were also more resistant than Kanro to an Illinois isolate of $P$. irregulare. The comparatively low aggressiveness of the $P$. sylvaticum isolate in the present study resulted in similar levels of disease on the susceptible check; thus, it is not possible to assess whether the resistance of the other four lines is also effective against P. sylvaticum, which Rojas et al. (2017a) found to be the most abundant Pythium spp. in soybean fields across Ontario, Canada, and 11 major soybean-producing U.S. states. The apparent weak aggressiveness of the $P$. sylvaticum isolate in the present study was surprising, considering that $P$. sylvaticum isolates caused considerable disease in assays conducted by Rojas et al. (2017a); however, data from their study also indicated that $P$. sylvaticum isolates caused more disease at 13 than at $20^{\circ} \mathrm{C}$. Because the inoculated millet seed in this experiment were incubated at 21 to $25^{\circ} \mathrm{C}$ and the greenhouse assay temperatures ranged from 16 to $21^{\circ} \mathrm{C}$, it is possible that the apparent aggressiveness of the isolate would have been higher at lower temperatures. In any case, the data from this experiment demonstrated that at least some of the accessions with resistance to the 12Py391 isolate of $P$. ultimum var. ultimum also have resistance to other pathogenic species of Pythium. Further assays are needed to determine the extent and level of resistance to different species and isolates.
The pedigrees of many cultivars developed by breeding programs in Canada and the north-central United States include one or more lines selected by Sven Holmberg of Algot Holmberg \& Söner AB in the town of Fiskeby, in Ostergotland, Sweden (Elovson 1997; Holmberg 1973). A diagram in Cober and Voldeng (2012) shows the presence of Fiskeby 840-7-3 (PI 438477) in the ancestry of numerous public cultivars released in Ontario between the mid-1970s and 2000. These cultivars include Maple Arrow (released in 1976), which was grown commercially for at least 13 years, and which is itself in the pedigrees of many other more recent cultivars. Fiskeby 840-7-3 was also an indirect ancestor of Maple Glen, which was released in 1988 and was grown commercially for at least 15 years, and of Maple Isle, which was partially resistant to $P$. ultimum var. ultimum in the present study. Maple Isle is a selection from a cross between PI 194641, another accession developed in Sweden, and Harosoy (Voldeng et al. 1985); thus, Pythium resistance could have been inherited from more than one of its progenitors. In addition to being an ancestor of a number of Canadian cultivars, Harosoy is in the pedigree of Archer (Cianzio et al. 1991; Cober and Voldeng 2012). Fiskeby III was one of the parents of Maple Ridge, a cultivar subsequently used in breeding programs in Minnesota and North Dakota (https://soybase.org/). The results of this study suggest the possibility that some high-yielding contemporary cultivars and breeding lines descended from the cold-tolerant Fiskeby lines identified through our assays could potentially be useful sources of resistance to Pythium root rot and damping-off.

Fiskeby III and Fiskeby 840-7-3 are closely related to each other. Fiskeby $840-7-3$ is from a cross of $201-14-20 \times 680+993+994$ (Müncheberg), and 201-14-20 is a sib of Fiskeby III (Bernard et al. 1988; Gizlice et al. 1994). Both were developed by Sven Holmberg in Sweden (Shurtleff and Aoyagi 2015). Although we do not know whether Maple Isle is directly related to Fiskeby 840-7-3 and Fiskeby III, it was derived from a cross to Holmberg 744-2, another line from the same breeding program at Fiskeby. Because Fiskeby III and Fiskeby 840-7-3 were not significantly different from each other in any of the pathogen screens, it is possible that they carry similar resistance genes. Although we do not know the origin of the Pythiumresistant ancestors of these lines, Holmberg collected seed of cold-tolerant landraces from Hokkaido and adjacent islands of the Okhotskh Sea, in northern Japan, in 1939 to 1940, and from the northern Amurskaja region of eastern Siberia (Holmberg 1973; Shurtleff and Aoyagi 2015). The 680+993+994 (Müncheberg) parent of Fiskeby 840-7-3 was developed at the Kaiser-Wilhelm-Institut für Züchtungsforschung in northeastern Germany, and might have also contributed useful resistance genes. Fiskeby III is also noteworthy for its tolerance to a number of abiotic stress conditions (Do et al. 2018).

Incorporation of early maturity and cold tolerance traits from the Swedish lines into the existing Canadian germplasm led to the development of cultivars that enabled the geographic expansion of soybean production northward and eastward in Ontario, and into Quebec and the Maritime provinces (Shurtleff and Aoyagi 2010; Voldeng et al. 1997). The abundance of $P$. ultimum found in the recent survey by Marchand et al. (2014) of soybean fields in Ontario suggests the possibility that resistance to P. ultimum var. ultimum could have been an important component of the "cold tolerance" that was transferred into at least some cultivars in the historically important Maple series of Canadian soybean cultivars from several Swedish lines developed by the soybean breeding program at Fiskeby. Because of the critical importance of cold tolerance and adaptation to latitudes with a short growing season, it seems likely that many modern cultivars adapted to Canada also have Swedish germplasm in their pedigrees. It is interesting, however, that both accessions of Fiskeby V (PI 360955A and PI 360955B) were part of the 16 lines with no seedling emergence when challenged with the $12 \mathrm{Py} 391$ isolate of P. ultimum var. ultimum, even though the noninoculated pots from these lines had greater than $90 \%$ germination.

Because Maple Isle was the only cultivar from the Maple series that was tested for resistance in our assays, it would be interesting to investigate whether other cultivars in the Maple series 
(i.e., Maple Arrow, Maple Amber, Maple Donovan, Maple Presto, and Maple Ridge) have similar levels of resistance to Pythium pathogens. All of these cultivars have the line Fiskeby 840-7-3 as a parent, except for Maple Isle (with Holmberg 744-2) and Maple Ridge, which had Fiskeby III as its maternal parent. The degree of genetic relationship between Holmberg 744-2 and Fiskeby 840-7-3 is not known to us. Most of the cultivars in the Maple series were developed from crosses to Harosoy, Harosoy 63, or Amsoy (Bernard et al.
1988); thus, they share progenitors with Archer. Harosoy and Amsoy were included in the first experiment, in which they had aboveaverage dry root and shoot weights, though Harosoy had a significantly greater plant stand than Amsoy (Table 2).

It was not surprising that none of the ancestral lines tested had high levels of resistance to the aggressive $P$. ultimum var. ultimum isolate used in this study, because high levels of resistance to Pythium pathogens appear to be uncommon in soybean (Rupe et al. 2011). This

Table 2. Relative mean plant stands and root and shoot dry weights of the 102 soybean lines used in the ancestral experiment that were screened for resistance against Pythium ultimum var. ultimum ${ }^{\mathrm{v}}$

\begin{tabular}{|c|c|c|c|c|}
\hline Accession & Cultivar name & Plant stand & Root dry weight ${ }^{w}$ & Shoot dry weightw \\
\hline FC 31745 & $\ldots$ & $0.06 \mathrm{P}-\mathrm{U}$ & $0.12 \mathrm{Q}-\mathrm{V}$ & $0.22 \mathrm{R}-\mathrm{BB}$ \\
\hline FC 33243 & Anderson & $0.09 \mathrm{~N}-\mathrm{U}$ & $0.19 \mathrm{~J}-\mathrm{V}$ & $0.25 \mathrm{Q}-\mathrm{BB}$ \\
\hline PI 54615-1 & No. 55 & $0.37 \mathrm{~B}-\mathrm{G}$ & $0.53 \mathrm{~B}-\mathrm{L}$ & $0.63 \mathrm{~A}-\mathrm{Q}$ \\
\hline PI 65338 & Botanical Garden No. 4 & $0.08 \mathrm{~N}-\mathrm{U}$ & 0.56 A-I & $0.54 \mathrm{C}-\mathrm{T}$ \\
\hline PI 71506 & No. 94 & $0.17 \mathrm{I}-\mathrm{T}$ & $0.42 \mathrm{~B}-\mathrm{S}$ & $0.62 \mathrm{~A}-\mathrm{R}$ \\
\hline PI 80837 & Mejiro & $0.25 \mathrm{D}-\mathrm{M}$ & $0.69 \mathrm{~A}-\mathrm{C}$ & $0.86 \mathrm{~A}-\mathrm{D}$ \\
\hline PI 84631 & S-56 & $0.02 \mathrm{~S}-\mathrm{U}$ & $0.03 \mathrm{UV}$ & $0.08 \mathrm{X}-\mathrm{BB}$ \\
\hline PI 84637 & S-62 & $0.47 \mathrm{AB}$ & $0.93 \mathrm{~A}$ & $0.87 \mathrm{~A}-\mathrm{C}$ \\
\hline PI 84946-2 & (Kandokon) & $0.13 \mathrm{~J}-\mathrm{U}$ & $0.54 \mathrm{~B}-\mathrm{K}$ & $0.53 \mathrm{C}-\mathrm{U}$ \\
\hline PI 86972-1 & Pakute & $0.06 \mathrm{Q}-\mathrm{U}$ & $0.33 \mathrm{C}-\mathrm{V}$ & $0.10 \mathrm{~W}-\mathrm{BB}$ \\
\hline PI 88788 & $\ldots$ & $0.02 \mathrm{~S}-\mathrm{U}$ & $0.17 \mathrm{~K}-\mathrm{V}$ & $0.03 \mathrm{AABB}$ \\
\hline PI 88811 & Pakute & $0.04 \mathrm{R}-\mathrm{U}$ & $0.27 \mathrm{E}-\mathrm{V}$ & $0.31 \mathrm{~N}-\mathrm{BB}$ \\
\hline PI 91110-1 & $\ldots$ & $0.35 \mathrm{~B}-\mathrm{H}$ & $0.60 \mathrm{~A}-\mathrm{F}$ & $0.71 \mathrm{~A}-\mathrm{L}$ \\
\hline PI 96983 & $\ldots$ & $0.02 \mathrm{~S}-\mathrm{U}$ & $0.17 \mathrm{~K}-\mathrm{V}$ & $0.16 \mathrm{~S}-\mathrm{BB}$ \\
\hline PI 159925 & Glycine H & $0 \mathrm{U}$ & $0 \mathrm{~V}$ & $0 \mathrm{BB}$ \\
\hline PI 171450 & Kisaya & 0.29 C-J & 0.46 B-Q & $0.43 \mathrm{G}-\mathrm{Z}$ \\
\hline PI 171451 & Kosamame & $0.15 \mathrm{I}-\mathrm{U}$ & $0.47 \mathrm{~B}-\mathrm{Q}$ & $0.50 \mathrm{C}-\mathrm{V}$ \\
\hline PI 180501 & Strain No. 18 & $0.18 \mathrm{I}-\mathrm{S}$ & $0.56 \mathrm{~A}-\mathrm{H}$ & $0.55 \mathrm{~B}-\mathrm{T}$ \\
\hline PI 200492 & Komata & $0.06 \mathrm{P}-\mathrm{U}$ & 0.42 B-S & $0.33 \mathrm{~J}-\mathrm{BB}$ \\
\hline PI 240664 & Bilomi \#3 & $0.10 \mathrm{M}-\mathrm{U}$ & $0.19 \mathrm{I}-\mathrm{V}$ & $0.38 \mathrm{G}-\mathrm{BB}$ \\
\hline PI 248404 & Novosadska Bela & $0.35 \mathrm{~B}-\mathrm{G}$ & $0.72 \mathrm{AB}$ & $0.71 \mathrm{~A}-\mathrm{M}$ \\
\hline PI 317335 & Koganejiro & $0.22 \mathrm{E}-\mathrm{O}$ & $0.14 \mathrm{O}-\mathrm{V}$ & $0.34 \mathrm{~J}-\mathrm{BB}$ \\
\hline PI 360955A & Fiskeby V & $0 \mathrm{U}$ & $0 \mathrm{~V}$ & $0 \mathrm{BB}$ \\
\hline PI 360955B & (Fiskeby V) & $0 \mathrm{U}$ & $0 \mathrm{~V}$ & $0 \mathrm{BB}$ \\
\hline PI 438471 & Fiskeby III & $0.37 \mathrm{~B}-\mathrm{F}$ & 0.67 A-D & $0.94 \mathrm{AB}$ \\
\hline PI 438477 & Fiskeby $840-7-3$ & $0.28 \mathrm{C}-\mathrm{K}$ & $0.58 \mathrm{~A}-\mathrm{F}$ & $0.76 \mathrm{~A}-\mathrm{G}$ \\
\hline PI 508269 & Stafford & $0.17 \mathrm{I}-\mathrm{T}$ & $0.57 \mathrm{~A}-\mathrm{G}$ & $0.53 \mathrm{C}-\mathrm{U}$ \\
\hline PI 513382 & Glenwood & $0.12 \mathrm{~K}-\mathrm{U}$ & 0.47 B-Q & 0.69 A-N \\
\hline PI 535807 & Crockett & $0.02 \mathrm{TU}$ & $0.17 \mathrm{~K}-\mathrm{V}$ & $0.17 \mathrm{~S}-\mathrm{BB}$ \\
\hline PI 542402 & Chico & $0.40 \mathrm{BCD}$ & 0.52 B-L & $0.69 \mathrm{~A}-\mathrm{N}$ \\
\hline PI 548169 & $\mathrm{~T} 117$ & $0.12 \mathrm{M}-\mathrm{U}$ & $0.41 \mathrm{~B}-\mathrm{S}$ & 0.73 A-J \\
\hline PI 548178 & $\mathrm{~T} 145$ & $0.17 \mathrm{I}-\mathrm{T}$ & $0.63 \mathrm{~A}-\mathrm{E}$ & $0.47 \mathrm{D}-\mathrm{Y}$ \\
\hline PI 548193 & T201 & $0.15 \mathrm{I}-\mathrm{U}$ & $0.31 \mathrm{D}-\mathrm{V}$ & $0.54 \mathrm{C}-\mathrm{T}$ \\
\hline PI 548195 & T204 & $0.30 \mathrm{C}-\mathrm{I}$ & 0.65 A-D & $0.84 \mathrm{~A}-\mathrm{F}$ \\
\hline PI 548237 & $\mathrm{~T} 260 \mathrm{H}$ & $0.05 \mathrm{R}-\mathrm{U}$ & $0.20 \mathrm{G}-\mathrm{V}$ & $0.30 \mathrm{~N}-\mathrm{BB}$ \\
\hline PI 548298 & A.K. (Harrow) & $0.08 \mathrm{~N}-\mathrm{U}$ & $0.21 \mathrm{G}-\mathrm{V}$ & $0.31 \mathrm{~N}-\mathrm{BB}$ \\
\hline PI 548301 & Aoda & $0.30 \mathrm{C}-\mathrm{I}$ & 0.64 A-D & $0.72 \mathrm{~A}-\mathrm{K}$ \\
\hline PI 548302 & Bansei & $0.15 \mathrm{I}-\mathrm{U}$ & $0.40 \mathrm{~B}-\mathrm{U}$ & $0.62 \mathrm{~A}-\mathrm{Q}$ \\
\hline PI 548307 & Blackeye & $0 \mathrm{U}$ & $0 \mathrm{~V}$ & $0 \mathrm{BB}$ \\
\hline PI 548311 & Capital & $0.10 \mathrm{M}-\mathrm{U}$ & $0.16 \mathrm{~L}-\mathrm{V}$ & $0.29 \mathrm{O}-\mathrm{BB}$ \\
\hline PI 548318 & Dunfield & $0.02 \mathrm{TU}$ & $0.07 \mathrm{R}-\mathrm{V}$ & $0.14 \mathrm{U}-\mathrm{BB}$ \\
\hline PI 548325 & Flambeau & $0.13 \mathrm{~K}-\mathrm{U}$ & $0.31 \mathrm{D}-\mathrm{V}$ & $0.47 \mathrm{D}-\mathrm{Y}$ \\
\hline PI 548336 & Habaro & $0.41 \mathrm{BC}$ & $0.40 \mathrm{~B}-\mathrm{T}$ & $0.56 \mathrm{~A}-\mathrm{S}$ \\
\hline PI 548342 & Higan & $0 \mathrm{U}$ & $0 \mathrm{~V}$ & $0 \mathrm{BB}$ \\
\hline PI 548348 & Illini & $0.07 \mathrm{O}-\mathrm{U}$ & $0.27 \mathrm{E}-\mathrm{V}$ & $0.51 \mathrm{C}-\mathrm{V}$ \\
\hline PI 548352 & Jogun & $0.23 \mathrm{E}-\mathrm{N}$ & $0.71 \mathrm{AB}$ & $0.95 \mathrm{~A}$ \\
\hline PI 548356 & Kanro & $0 \mathrm{U}$ & $0 \mathrm{~V}$ & $0 \mathrm{BB}$ \\
\hline PI 548359 & Kingwa & $0 \mathrm{U}$ & $0 \mathrm{~V}$ & $0 \mathrm{BB}$ \\
\hline PI 548360 & Korean & $0 \mathrm{U}$ & $0 \mathrm{~V}$ & $0 \mathrm{BB}$ \\
\hline \multirow[t]{2}{*}{ PI 548362} & Lincoln & $0.04 \mathrm{R}-\mathrm{U}$ & $0.24 \mathrm{~F}-\mathrm{V}$ & $0.38 \mathrm{G}-\mathrm{BB}$ \\
\hline & & & & (Continued on next page) \\
\hline
\end{tabular}

${ }^{v}$ Soybean lines include 90 ancestral and first progeny lines, the resistant check Archer, 10 lines in Archer's pedigree, and 2 susceptible checks of Jack and Sloan. Each of the inoculated replications was compared with its noninoculated control. Fisher's protected least significant difference (LSD) was used for LS means separation.

${ }^{\text {w }}$ Relative weights used were on a per-plant basis of the inoculated replications to their noninoculated control.

x Resistant check.

y Susceptible check.

${ }^{\mathrm{z}}$ Overall mean of inoculated replications for plant stand, dry root weight, or dry shoot weight. 
might be due to the biology and genome of Pythium spp., which differ from Phytophthora pathogens in being adapted to a necrotrophic lifestyle and in lacking RxLR effectors (Adhikari et al. 2013; Glazebrook 2005; Lévesque et al. 2010; van West et al. 2003). In contrast, pathogenic Phytophthora spp. carry genes for hundreds of RxLR effectors that are thought to be associated with entry into host cells and suppression of host defense responses. Recognition of some RxLR effectors by plant immune receptors results in programmed cell death and resistance to incompatible races of Phytophthora spp. (Adhikari et al. 2013; Laviolette et al. 1979). It is possible that the absence of this class of effectors in Pythium pathogens allows them to evade the type of gene-for-gene interactions that characterize relationships between Phytophthora sojae races and soybean plants carrying major Rps resistance genes, thus avoiding a strong host defensive reaction. Although Rosso et al. (2008) found that a single major resistance gene on soybean chromosome 13 (linkage group F)

Table 2. (Continued from previous page)

\begin{tabular}{|c|c|c|c|c|}
\hline Accession & Cultivar name & Plant stand & Root dry weight ${ }^{w}$ & Shoot dry weight ${ }^{w}$ \\
\hline PI 548379 & Mandarin (Ottawa) & $0.08 \mathrm{~N}-\mathrm{U}$ & $0.24 \mathrm{~F}-\mathrm{V}$ & $0.45 \mathrm{~F}-\mathrm{Y}$ \\
\hline PI 548382 & Manitoba Brown & $0.08 \mathrm{~N}-\mathrm{U}$ & $0.51 \mathrm{~B}-\mathrm{O}$ & $0.61 \mathrm{~A}-\mathrm{R}$ \\
\hline PI 548383 & Mansoy & $0.03 \mathrm{~S}-\mathrm{U}$ & $0.06 \mathrm{R}-\mathrm{V}$ & $0.33 \mathrm{~K}-\mathrm{BB}$ \\
\hline PI 548391 & Mukden & $0.10 \mathrm{M}-\mathrm{U}$ & $0.42 \mathrm{~B}-\mathrm{S}$ & $0.52 \mathrm{C}-\mathrm{V}$ \\
\hline PI 548402 & Peking & $0.02 \mathrm{TU}$ & $0.17 \mathrm{~K}-\mathrm{V}$ & 0.17 S-BB \\
\hline PI 548406 & Richland & $0.37 \mathrm{~B}-\mathrm{G}$ & $0.61 \mathrm{~A}-\mathrm{E}$ & $0.70 \mathrm{~A}-\mathrm{N}$ \\
\hline PI 548409 & Sato & $0.28 \mathrm{C}-\mathrm{L}$ & 0.55 B-J & 0.65 A-P \\
\hline PI 548411 & Seneca & $0.07 \mathrm{O}-\mathrm{U}$ & $0.49 \mathrm{~B}-\mathrm{P}$ & $0.35 \mathrm{~J}-\mathrm{BB}$ \\
\hline PI 548438 & Arksoy & $0 \mathrm{U}$ & $0 \mathrm{~V}$ & $0 \mathrm{BB}$ \\
\hline PI 548444 & Biloxi & $0.08 \mathrm{~N}-\mathrm{U}$ & $0.17 \mathrm{~K}-\mathrm{V}$ & $0.36 \mathrm{H}-\mathrm{BB}$ \\
\hline PI 548445 & CNS & 0.22 F-P & 0.55 B-J & $0.76 \mathrm{~A}-\mathrm{H}$ \\
\hline PI 548456 & Haberlandt & $0 \mathrm{U}$ & $0 \mathrm{~V}$ & $0 \mathrm{BB}$ \\
\hline PI 548457 & Hahto & $0.02 \mathrm{~S}-\mathrm{U}$ & $0.05 \mathrm{~S}-\mathrm{V}$ & $0.12 \mathrm{~V}-\mathrm{BB}$ \\
\hline PI 548461 & Improved Pelican & $0.10 \mathrm{M}-\mathrm{U}$ & $0.46 \mathrm{~B}-\mathrm{Q}$ & $0.40 \mathrm{G}-\mathrm{AA}$ \\
\hline PI 548463 & Laredo & $0.09 \mathrm{~N}-\mathrm{U}$ & $0.40 \mathrm{~B}-\mathrm{U}$ & $0.66 \mathrm{~A}-\mathrm{P}$ \\
\hline PI 548469 & Mammoth Yellow & $0 \mathrm{U}$ & $0 \mathrm{~V}$ & $0 \mathrm{BB}$ \\
\hline PI 548477 & Ogden & $0.23 \mathrm{E}-\mathrm{N}$ & $0.40 \mathrm{~B}-\mathrm{U}$ & $0.69 \mathrm{~A}-\mathrm{N}$ \\
\hline PI 548484 & Ralsoy & $0 \mathrm{U}$ & $0 \mathrm{~V}$ & $0 \mathrm{BB}$ \\
\hline PI 548485 & Roanoke & $0.02 \mathrm{TU}$ & $0.15 \mathrm{M}-\mathrm{V}$ & $0.10 \mathrm{~W}-\mathrm{BB}$ \\
\hline PI 548488 & S-100 & $0.03 \mathrm{~S}-\mathrm{U}$ & $0.04 \mathrm{~T}-\mathrm{V}$ & $0.09 \mathrm{X}-\mathrm{BB}$ \\
\hline PI 548493 & Tokyo & $0.02 \mathrm{TU}$ & $0.14 \mathrm{~N}-\mathrm{V}$ & $0.04 \mathrm{Z}-\mathrm{BB}$ \\
\hline PI 548494 & Volstate & $0 \mathrm{U}$ & $0 \mathrm{~V}$ & $0 \mathrm{BB}$ \\
\hline PI 548528 & Protana & 0.04 R-U & $0.27 \mathrm{E}-\mathrm{V}$ & $0.26 \mathrm{R}-\mathrm{BB}$ \\
\hline PI 548548 & Delmar & $0.49 \mathrm{AB}$ & $0.57 \mathrm{~A}-\mathrm{G}$ & $0.69 \mathrm{~A}-\mathrm{N}$ \\
\hline PI 548559 & Emerald & $0.11 \mathrm{M}-\mathrm{U}$ & $0.51 \mathrm{~B}-\mathrm{M}$ & 0.66 A-P \\
\hline PI 548561 & Hodgson & $0.38 \mathrm{~B}-\mathrm{E}$ & 0.46 B-Q & $0.50 \mathrm{C}-\mathrm{X}$ \\
\hline PI 548587 & Kim & $0 \mathrm{U}$ & $0 \mathrm{~V}$ & $0 \mathrm{BB}$ \\
\hline PI 548595 & Maple Isle & $0.57 \mathrm{~A}$ & $0.61 \mathrm{~A}-\mathrm{E}$ & $0.68 \mathrm{~A}-\mathrm{O}$ \\
\hline PI 548599 & Monroe & $0.06 \mathrm{Q}-\mathrm{U}$ & $0.04 \mathrm{~T}-\mathrm{V}$ & 0.08 Y-BB \\
\hline PI 548603 & Perry & $0.11 \mathrm{M}-\mathrm{U}$ & $0.35 \mathrm{~B}-\mathrm{V}$ & $0.56 \mathrm{~A}-\mathrm{S}$ \\
\hline PI 548604 & Pershing & $0.16 \mathrm{I}-\mathrm{T}$ & 0.55 B-J & 0.59 A-R \\
\hline PI 548623 & Vansoy & $0.12 \mathrm{M}-\mathrm{U}$ & 0.49 B-P & 0.43 G-AA \\
\hline PI 548626 & Wabash & $0.03 \mathrm{~S}-\mathrm{U}$ & $0.20 \mathrm{H}-\mathrm{V}$ & $0.32 \mathrm{M}-\mathrm{BB}$ \\
\hline PI 548633 & Wye & 0.22 F-P & $0.53 \mathrm{~B}-\mathrm{K}$ & $0.45 \mathrm{~F}-\mathrm{Y}$ \\
\hline PI 548657 & Jackson & $0.12 \mathrm{~L}-\mathrm{U}$ & $0.33 \mathrm{C}-\mathrm{V}$ & $0.32 \mathrm{~L}-\mathrm{BB}$ \\
\hline PI 548663 & Dowling & $0.05 \mathrm{R}-\mathrm{U}$ & 0.47 B-Q & $0.33 \mathrm{~K}-\mathrm{BB}$ \\
\hline PI 548697 & Majos & $0 \mathrm{U}$ & $0 \mathrm{~V}$ & $0 \mathrm{BB}$ \\
\hline PI 548983 & Tracy & 0.04 R-U & $0.08 \mathrm{R}-\mathrm{V}$ & 0.22 R-BB \\
\hline PI 553048 & Vance & 0.04 R-U & $0.17 \mathrm{~K}-\mathrm{V}$ & $0.16 \mathrm{~T}-\mathrm{BB}$ \\
\hline PI 567790 & Curtis & 0.05 R-U & $0.27 \mathrm{E}-\mathrm{V}$ & $0.37 \mathrm{G}-\mathrm{BB}$ \\
\hline PI 546487 & Archer ${ }^{\mathrm{x}}$ & $0.35 \mathrm{~B}-\mathrm{G}$ & $0.59 \mathrm{~A}-\mathrm{F}$ & 0.75 A-I \\
\hline PI 548519 & BSR-101 & $0.09 \mathrm{M}-\mathrm{U}$ & $0.32 \mathrm{D}-\mathrm{V}$ & $0.63 \mathrm{~A}-\mathrm{Q}$ \\
\hline PI 548506 & Amsoy & $0.09 \mathrm{M}-\mathrm{U}$ & 0.43 B-R & $0.46 \mathrm{E}-\mathrm{Y}$ \\
\hline PI 548527 & Calland & 0.29 C-I & $0.48 \mathrm{~B}-\mathrm{Q}$ & $0.56 \mathrm{~A}-\mathrm{T}$ \\
\hline PI 548502 & Adams & $0 \mathrm{U}$ & $0 \mathrm{~V}$ & $0 \mathrm{BB}$ \\
\hline PI 548573 & Harosoy & $0.58 \mathrm{~A}$ & 0.55 B-J & 0.85 A-E \\
\hline PI 548504 & Altona & $0.21 \mathrm{G}-\mathrm{Q}$ & 0.55 B-J & $0.48 \mathrm{C}-\mathrm{X}$ \\
\hline PI 548516 & Blackhawk & 0.29 C-J & $0.37 \mathrm{~B}-\mathrm{U}$ & $0.64 \mathrm{~A}-\mathrm{Q}$ \\
\hline PI 518671 & Williams 82 & $0.28 \mathrm{C}-\mathrm{L}$ & $0.51 \mathrm{~B}-\mathrm{N}$ & $0.75 \mathrm{~A}-\mathrm{H}$ \\
\hline PI 548533 & Clark & $0.12 \mathrm{M}-\mathrm{U}$ & $0.27 \mathrm{E}-\mathrm{V}$ & $0.36 \mathrm{I}-\mathrm{BB}$ \\
\hline PI 540556 & $\mathrm{Jack}^{\mathrm{y}}$ & 0.19 H-R & $0.39 \mathrm{~B}-\mathrm{U}$ & $0.43 \mathrm{G}-\mathrm{Z}$ \\
\hline PI 548616 & Sloan ${ }^{y}$ & $0.25 \mathrm{D}-\mathrm{M}$ & $0.12 \mathrm{R}-\mathrm{V}$ & 0.42 G-AA \\
\hline $\operatorname{LSD}(P \leq 0.05)$ & $\ldots$ & 0.18 & 0.43 & 0.44 \\
\hline Standard error & $\ldots$ & 0.058 & 0.148 & 0.145 \\
\hline Overall mean ${ }^{z}$ & $\ldots$ & 0.140 & 0.323 & 0.399 \\
\hline
\end{tabular}


from Archer named Rpal conferred a high level of resistance to Pythium aphanidermatum following hypocotyl inoculations, Urrea et al. (2017) reported that two independent quantitative trait loci (QTL) were associated with Archer's resistance to seed and root rot caused by $P$. aphanidermatum. Mahuku et al. (2005) found that resistance to P. ultimum var. ultimum in common bean (Phaseolus vulgaris) was also conditioned by a single dominant gene.

It was also not surprising that the lines with partial resistance were in MG 00 to IV, and had originated from cool, temperate regions of several different countries (https://www.ars-grin.gov/), because P. ultimum var. ultimum is adapted to cool conditions and can be found around the world (van der Plaats-Niterink 1981). Recent surveys have confirmed that Pythium pathogens, particularly $P$. ultimum var. ultimum and $P$. sylvaticum, are abundant in the rhizosphere of soybean fields in Ontario and the upper Midwest and north-central United States (Marchand et al. 2014; Rojas et al. 2017a,b; ZitnickAnderson and Nelson 2015).

We did expect Archer to have a higher level of resistance, because it had been reported by Bates et al. (2008) to have some resistance against $P$. ultimum, $P$. aphanidermatum, $P$. irregular, and $P$. vexans. Based on root and shoot dry weight ratios, Archer showed partial resistance to the $12 \mathrm{Py} 391$ isolate of P. ultimum var. ultimum (Table 2). The $P$. ultimum isolate that Bates et al. (2008) and Kirkpatrick et al. (2006a) used to challenge Archer was a 1999 isolate from Arkansas. We do not know how the pathotype of the 12Py391 isolate compares with that of the Arkansas isolate but, because P. ultimum var. sporangiiferum is less common, it seems likely that the Arkansas isolate would have also been the variety ultimum. Different assay methods or reaction rating methods, or differences in the aggressiveness of the isolates, could have also contributed to the differences observed in the apparent resistance of Archer. Urrea et al. (2017) recently discovered two QTL associated with the resistance of Archer to P. aphanidermatum; therefore, it will be interesting to see whether those are also involved in resistance to other Pythium spp. The locations of these QTL (on chromosomes 4 and 7) differed from the chromosome 13 location of the dominant Rpal gene identified by Rosso et al. (2008) using a hypocotyl inoculation assay. Urrea et al. (2017) hypothesized that the different results might have been due to their use of infested vermiculite and seed plating assays that measure seed and root rot rather than plant survival, which is used to assess resistance following hypocotyl inoculation. It would also be interesting to know whether the QTL for resistance to seed and root rot caused by $P$. aphanidermatum are associated with $P$. ultimum var. ultimum resistance in any of the lines that appeared to be resistant in the present study.

A single isolate was used to represent each of the three Pythium spp. in the second experiment. We do not know how well those

Table 3. Spearman rank correlations between relative plant stand, root dry weight, and shoot dry weight in the ancestral screen experiment ${ }^{\mathrm{Z}}$

\begin{tabular}{lccc}
\hline Variables & Plant stand & Root dry weight & Shoot dry weight \\
\hline Plant stand & 1 & 0.82638 & 0.8136 \\
Root dry weight & $\ldots$ & 1 & 0.8782 \\
Shoot dry weight & $\ldots$ & $\ldots$ & 1
\end{tabular}

${ }^{\mathrm{z}}$ Weights used were on a per-plant basis. All correlations are significant $(P \leq$ 0.0001).

Table 4. Spearman rank correlations between pairs of resistance evaluation trait ratios in assays with isolates of Pythium ultimum var. ultimum, P. irregulare, and P. sylvaticum ${ }^{\mathrm{z}}$

\begin{tabular}{lccc}
\hline Variables & Plant stand & Root dry weight & Shoot dry weight \\
\hline Plant stand & 1 & 0.59 & 0.34 \\
Root dry weight & $\ldots$ & 1 & 0.59 \\
Shoot dry weight & $\ldots$ & $\ldots$ & 1
\end{tabular}

${ }^{\mathrm{z}}$ Weights used were on a per-plant basis. All correlations are significant $(P \leq$ $0.0001)$. isolates represented the average pathogenicity of North American populations of those species but the 12Py391 isolate was more aggressive than some other $P$. ultimum var. ultimum isolates in preliminary assays. Our observation that $P$. ultimum var. ultimum was more aggressive than $P$. irregulare, which was more aggressive than $P$. sylvaticum, should therefore be confirmed using other isolates. The weak aggressiveness of the $P$. sylvaticum isolate used, even toward Kanro, makes it unclear whether all five lines are actually resistant or if soybean is simply not a good host for this species or isolate.

Soybean disease caused by Pythium pathogens can occur as a seed rot phase or a root rot phase, and some host resistance genes may not necessarily provide protection from both (Rupe et al. 2011). Different types of assays have been developed to assess resistance to disease of seed, seedlings, or both. The ability of a pathotype to colonize seed from different soybean genotypes can be measured using Petri plate assays (Dorrance et al. 2004). Some types of seedling resistance to Pythium spp. can be measured using a hypocotyl inoculation assay of the type that Rosso et al. (2008) used to assess $P$. aphanidermatum resistance inherited from Archer. This method, which was originally developed for Phytophthora sojae assays, was found to be effective and more consistent than a sand/cornmeal inoculum layer method that was also tested by Rosso et al. (2008). We were unable to obtain consistent differences in reactions, however, when we tested the hypocotyl inoculation method with the 12Py391 isolate and cultivars (data not shown).

The inoculum-layer assay used in the present study revealed variation among soybean lines for both seedling emergence and seedling growth and, thus, provided information about levels of seed rot and stunting of seedlings in pots with inoculum. In our assays, the seed were separated from the layer of inoculum by $2.5 \mathrm{~cm}$ of potting soil, preventing direct contact between the inoculum and the seed. In contrast, Bates et al. (2008) conducted inoculum layer emergence assays in which the seed were placed directly onto the inoculum, and an establishment assay in which a 1.8 -mm layer of pasteurized soil separated the seed from the inoculum. This thin barrier likely exposed seed to the pathogen considerably earlier than the $2.5-\mathrm{cm}$ layer used in our assays, which could influence observed levels of preemergence damping-off. Because soil saturation and flooding often

Table 5. Relative means for resistance evaluation traits measured on plants of four soybean lines inoculated with Pythium ultimum var. ultimum, P. irregulare, and $P$. sylvaticum compared with noninoculated controls of the same line $^{\mathrm{z}}$

\begin{tabular}{llll}
\hline $\begin{array}{l}\text { Pythium spp. and lines } \\
\text { screened }\end{array}$ & $\begin{array}{c}\text { Plant } \\
\text { stand }\end{array}$ & $\begin{array}{c}\text { Root dry } \\
\text { weight }\end{array}$ & $\begin{array}{c}\text { Shoot dry } \\
\text { weight }\end{array}$ \\
\hline $\begin{array}{l}\text { P. ultimum var. ultimum } \\
\text { PI 84637 }\end{array}$ & $0.82 \mathrm{~A}$ & $0.62 \mathrm{~A}$ & $0.83 \mathrm{~A}$ \\
Maple Isle & $0.61 \mathrm{~B}$ & $0.58 \mathrm{AB}$ & $0.76 \mathrm{~A}$ \\
Fiskeby III & $0.60 \mathrm{~B}$ & $0.56 \mathrm{AB}$ & $0.76 \mathrm{~A}$ \\
Fiskeby 840-7-3 & $0.67 \mathrm{AB}$ & $0.42 \mathrm{BC}$ & $0.71 \mathrm{~A}$ \\
Kanro & $0.13 \mathrm{C}$ & $0.27 \mathrm{C}$ & $0.41 \mathrm{~B}$ \\
Standard error & 0.062 & 0.086 & 0.069 \\
P. irregulare & & & \\
PI 84637 & $0.96 \mathrm{~A}$ & $0.94 \mathrm{~A}$ & $0.82 \mathrm{~A}$ \\
Maple Isle & $0.73 \mathrm{~B}$ & $0.64 \mathrm{~B}$ & $0.66 \mathrm{~A}$ \\
Fiskeby III & $0.75 \mathrm{~B}$ & $0.59 \mathrm{~B}$ & $0.80 \mathrm{~A}$ \\
Fiskeby 840-7-3 & $0.70 \mathrm{~B}$ & $0.50 \mathrm{~B}$ & $0.69 \mathrm{~A}$ \\
Kanro & $0.33 \mathrm{C}$ & $0.55 \mathrm{~B}$ & $0.74 \mathrm{~A}$ \\
Standard error & 0.052 & 0.065 & 0.083 \\
P. sylvaticum & & & \\
PI 84637 & $0.97 \mathrm{~A}$ & $0.96 \mathrm{AB}$ & $0.94 \mathrm{AB}$ \\
Maple Isle & $0.94 \mathrm{~A}$ & $0.99 \mathrm{~A}$ & $0.91 \mathrm{~B}$ \\
Fiskeby III & $0.94 \mathrm{~A}$ & $0.98 \mathrm{AB}$ & $0.96 \mathrm{~A}$ \\
Fiskeby 840-7-3 & $0.84 \mathrm{~B}$ & $0.94 \mathrm{AB}$ & $0.95 \mathrm{AB}$ \\
Kanro & $0.93 \mathrm{~A}$ & $0.92 \mathrm{~B}$ & $0.98 \mathrm{~A}$ \\
Standard error & 0.024 & 0.020 & 0.028 \\
\hline
\end{tabular}

${ }^{\mathrm{z}}$ Fisher's least significant difference was used to determine significant differences. Means followed by the same letter within a column are not significantly different $(P \leq 0.05)$. Weights used were on a per-plant basis. 
exacerbate soybean pre- and postemergence damping off caused by Pythium pathogens (Kirkpatrick et al. 2006a), the composition of the soil or soil mix used in inoculum-layer assays could also influence the severity of disease and rot observed in assays. As mentioned earlier, temperature differences in assays conducted by different research groups may have also contributed to differences in the perceived aggressiveness of different isolates and species of Pythium. Although each type of assay has its merits and disadvantages, the inclusion of noninoculated or mock-inoculated control treatments and known susceptible hosts in each assay provides a critical indication of the success of each experiment and assay method to distinguish between resistant and susceptible plants.

Statistical sensitivity in future assays could likely be improved to decrease the large standard errors that we had in the present study, particularly for root and shoot dry weight ratios, by increasing the number of inoculated replications per line or the number of plants per replication. In addition, experimental error resulting from random differences in the rate of water absorption, germination, and emergence of seed in the same pot should be reduced, if possible, because variation in emergence rates results in broader differences in root and shoot dry weights among noninoculated control plants. Aggressiveness levels among and within Pythium spp. vary (Broders et al. 2007; Radmer et al. 2017), which contributes to variation in seedling emergence and vigor.

From this study, we conclude that sources for resistance to $P$. ultimum var. ultimum exist in the genetic base of North American soybean cultivars released prior to 1989 , and that some of those might also have resistance to other Pythium spp. These resistant accessions originated from several different countries but germplasm accessions originating from northeastern China, Korea, and northern Japan, or North American cultivars derived from them, might have a higher than average probability of being resistant, though some of the lines we screened from those regions in this study were susceptible. Recently developed, early-maturing cultivars descended from Fiskeby III or the Fiskeby 840-7-3 line might also prove to be good sources of Pythium resistance genes. We also showed that some of the same lines with partial resistance to $P$. ultimum var. ultimum were partially resistant to an isolate of $P$. irregulare, another common soil pathogen of soybean grown in North America. More research is needed to determine whether the same or different genes are responsible for partial resistance to different species of Pythium, and whether the resistant lines identified here are also resistant to other Pythium spp. and isolates. Although seed treatments with fungicides that protect soybean seed and seedlings from Pythium pathogens as well as fungi have become common for seed marketed in North America, resistance to Pythium pathogens could help to protect seedlings after their roots grow beyond the activity zone of the seed fungicides and when environmental conditions are particularly favorable for Pythium spp. pathogens.

\section{Acknowledgments}

We thank U. Reuter-Carlson, A. Taylor, and M. K. "Katey" Pauls for invaluable assistance in the laboratory and greenhouse.

\section{Literature Cited}

Adhikari, B. N., Hamilton, J. P., Zerillo, M. M., Tisserat, N., Lévesque, C. A., and Buell, C. R. 2013. Comparative genomics reveals insight into virulence strategies of plant pathogenic oomycetes. PLoS One 8:e75072.

Bates, G. D., Rothrock, C. S., and Rupe, J. C. 2008. Resistance of the soybean cultivar Archer to Pythium damping-off and root rot caused by several Pythium spp. Plant Dis. 92:763-766.

Bernard, R. L., Cremeens, C. R., Cooper, R. L., Collins, F. I., Krober, O. A., Athow, K. L., Laviolette, F. A., Coble, C. J., and Nelson, R. L. 1998. Evaluation of the USDA Soybean Germplasm Collection: Maturity groups 000-IV (FC 01.547-PI 266.807). Tech. Bull. USDA 1844:30-85.

Bernard, R. L., Juvik, G. A., Hartwig, E. E., and Edwards, C. J., Jr. 1988. Origins and Pedigrees of Public Soybean Varieties in the United States and Canada. U.S. Dep. Agric. Agric. Res. Serv. Tech. Bull. No. 1746.

Bradley, C. A., Hartman, G. L., Nelson, R. L., Mueller, D. S., and Pedersen, W. L. 2001. Response of ancestral soybean lines and commercial cultivars to Rhizoctonia root and hypocotyl rot. Plant Dis. 85:1091-1095.

Broders, K. D., Lipps, P. E., Paul, P. A., and Dorrance, A. E. 2007. Characterization of Pythium spp. associated with corn and soybean seed and seedling diseases in Ohio. Plant Dis. 91:727-735.
Broders, K. D., Wallhead, M. W., Austin, G. D., Lipps, P. E., Paul, P. A., Mullen, R. W., and Dorrance, A. E. 2009. Association of soil chemical and physical properties with Pythium species diversity, community, composition, and disease incidence. Phytopathology 99:957-967.

Brown, G. E., and Kennedy, B. W. 1965. Pythium pre-emergence damping-off in soybean in Minnesota. Plant Dis. Rep. 49:646-647.

Cianzio, S. R., Schultz, S. P., Fehr, W. R., and Tachibana, H. 1991. Registration of 'Archer' soybean. Crop Sci. 31:1707.

Cober, E. R., and Voldeng, H. D. 2012. A retrospective look at short-season soybean cultivar development in Ontario. Can. J. Plant Sci. 92:1239-1243.

Crittenden, H. W., and Cole, R. H. 1967. Registration of 'Delmar' soybean. Crop Sci. 7:279.

Do, T. D., Vuong, T. D., Dunn, D., Smothers, S., Patil, G., Yungbluth, D. C., Chen, P., Scaboo, A., Xu, D., Carter, T. E., Nguyen, H. T., and Shannon, J. G. 2018. Mapping and confirmation of loci for salt tolerance in a novel soybean germplasm, Fiskeby III. Theor. Appl. Genet. 131:513-524.

Dorrance, A. E., Berry, S. A., Bowen, P., and Lipps, P. E. 2004. Characterization of Pythium spp. from three Ohio fields for pathogenicity on corn and soybean and metalaxyl sensitivity. Online publication. Plant Health Prog. doi.org/10.1094/ PHP-2004-0202-01-RS

Ellis, M. L., McHale, L. K., Paul, P. A., St. Martin, S. K., and Dorrance, A. E. 2013. Soybean germplasm resistant to Pythium irregulare and molecular mapping of resistance quantitative trail loci derived from the soybean accession PI 424354. Crop Sci. 53:1008-1021.

Elovson, R. 1997. Algot Homberg \& Söner AB. Pages 81-84 in: "Den Svenska Växtförädlingens Historia. Jordbruksvästenas utveckling sedan 1880-talet". Gösta Olsson, ed. Kungl. Skogs- och Landbruksakad., Stockholm. (In Swedish).

Francis, D. M., and St. Clair, D. A. 1997. Population genetics of Pythium ultimum Phytopathology 87:454-461.

Gizlice, Z., Carter, T. E., and Burton, J. W. 1994. Genetic base for North American public soybean cultivars released between 1947 and 1988. Crop Sci. 34: 1143-1151.

Glazebrook, J. 2005. Contrasting mechanisms of defense against biotrophic and necrotrophic pathogens. Annu. Rev. Phytopathol. 43:205-227.

Grau, C. R., Dorrance, A. E., Bond, J., and Russin, J. S. 2004. Fungal diseases. Pages 679-764 in: Soybean: Improvement, Production, and Uses. Third Edition. H. R. Boerma and J. E. Specht, eds. American Society of Agronomy, Inc., Crop Science Society of America, Inc., and Soil Science Society of American, Inc., Madison WI.

Griffin, G. J. 1990. Importance of Pythium ultimum in a disease syndrome of cv. Essex soybean. Can. J. Plant Pathol. 12:135-140.

Holmberg, S. A. 1973. Soybeans for cool temperate climates. Agri. Hort. Genet 31:1-20.

Hu, M., and Wiatrak, P. 2012. Effect of planting date on soybean growth, yield, and grain quality: A review. Agron. J. 104:785-790.

Jiang, Y. N., Haudenshield, J. S., and Hartman, G. L. 2012. Characterization of Pythium spp. from soil samples in Illinois. Can. J. Plant Pathol. 34:448-454.

Keeling, B. L. 1974. Soybean seed rot and relation of seed exudate to host susceptibility. Phytopathology 64:1445-1447.

Kirkpatrick, M. T., Rothrock, C. S., Rupe, J. C., and Gbur, E. E. 2006a. The effect of Pythium ultimum and soil flooding on two soybean cultivars. Plant Dis. 90 : 597-602.

Kirkpatrick, M. T., Rupe, J. C., and Rothrock, C. S. 2006b. Soybean response to flooded soil conditions and the association with soilborne plant pathogenic genera. Plant Dis. 90:592-596.

Lambert, J. W., and Kennedy, B. W. 1975. Registration of Evans and Hodgson soybeans (Reg. Nos. 109 and 110). Crop Sci. 15:735.

Laviolette, F. A., Athow, K. L., Mueller, E. H., and Wilcox, J. R. 1979. Inheritance of resistance in soybean to physiologic races 5, 6, 7, 8, and 9 of Phytophthora megasperma var. sojae. Phytopathology 69:270-271.

Lévesque, C. A., Brouwer, H., Cano, L., Hamilton, J. P., Holt, C., Huitema, E., Raffaele, S., Robideau, G. P., Thines, M., Win, J., et al. 2010. Genome sequence of the necrotrophic plant pathogen Pythium ultimum reveals original pathogenicity mechanisms and effector repertoire. Genome Biol. 11:R73.

Lévesque, C. A., and De Cock, A. W. 2004. Molecular phylogeny and taxonomy of the genus Pythium. Mycol. Res. 108:1363-1383.

Mahuku, G. S., Buruchara, R. A., and Navia, M. 2005. A gene that confers resistance to Pythium root rot in common bean: Genetic characterization and development of molecular markers. Phytopathology 95:S94.

Marchand, G., Chen, Y., Berhane, N. A., Wei, L., Lévesque, C. A., and Xue, A. G. 2014. Identification of Pythium spp. from the rhizosphere of soybeans in Ontario, Canada. Can. J. Plant Pathol. 36:246-251.

McLachlan, K. S. 2016. Evaluation of Pythium root rot and damping off resistance in the ancestral lines of North American soybean cultivars and chemical control of the active ingredient ethaboxam in seed treatments. M.S. thesis, Department of Crop Sciences, The University of Illinois at Urbana-Champaign, Urbana.

Mueller, D. S., Nelson, R. L., Hartman, G. L., and Pedersen, W. L. 2003. Response of commercially developed soybean cultivars and the ancestral soybean lines to Fusarium solani f. sp. glycines. Plant Dis. 87:827-831.

Orf, J. H., Lambert, J. W., and Kennedy, B. W. 1985. Registration of 'Chico' soybean. Crop Sci. 25:711. 
Pawlowski, M. L., Hill, C. B., and Hartman, G. L. 2015. Resistance to charcoal rot identified in ancestral soybean germplasm. Crop Sci. 55:1230-1235.

Radmer, L., Anderson, G., Malvick, D. M., and Kurle, J. E. 2017. Pythium, Phytophthora, and Phytopythium spp. associated with soybean in Minnesota, their relative aggressiveness on soybean and corn, and their sensitivity to seed treatment fungicides. Plant Dis. 101:62-72.

Robinson, A. P., Conley, S. P., Volenec, J. J., and Santini, J. B. 2009. Analysis of high yielding, early-planted soybean in Indiana. Agron. J. 101:131-139.

Rojas, J. A., Jacobs, J. L., Napieralski, S., Karaj, B., Bradley, C. A., Chase, T., Esker, P. D., Giesler, L. D., Jardine, D. J., Malvick, D. K., Markell, S. G., Nelson, B. D., Robertson, A. E., Rupe, J. C., Smith, D. L., Sweets, L. E., Tenuta, A. U., Wise, K. A., and Chilvers, M. I. 2017a. Oomycete species associated with soybean seedlings in North America-Part I: Identification and pathogenicity characterization. Phytopathology 107:280-292.

Rojas, J. A., Jacobs, J. L., Napieralski, S., Karaj, B., Bradley, C. A., Chase, T., Esker, P. D., Giesler, L. D., Jardine, D. J., Malvick, D. K., Markell, S. G., Nelson, B. D., Robertson, A. E., Rupe, J. C., Smith, D. L., Sweets, L. E., Tenuta, A. U., Wise, K. A., and Chilvers, M. I. 2017b. Oomycete species associated with soybean seedlings in North America-Part II: Diversity and ecology in relation to environmental and edaphic factors. Phytopathology 107:293-304.

Rosso, M. L., Rupe, J. C., Chen, P., and Mozzoni, L. A. 2008. Inheritance and genetic mapping of resistance to Pythium damping-off caused by Pythium aphanidermatum in 'Archer' soybean. Crop Sci. 48:2215-2222.

Rothrock, C. S., Avanzato, M. V., and Rupe, J. C. 2015. Pythium seed rot, damping-off, and root rot. Pages 76-79 in: Compendium of Soybean Diseases and Pests, 5th ed. G. L. Hartman, J. C. Rupe, E. J. Sikora, L. L. Domier, J. A. Davis, and K. L. Steffey, eds. American Phytopathological Society, St. Paul, MN.

Rupe, J. C., Rothrock, C. S., Bates, G., Rosso, M. L., Avanzato, M. V., and Chen, P. 2011. Resistance to Pythium seedling disease in soybean. Chapter 12 in: Soybean-Molecular Aspects of Breeding. A. Sudarić, ed. InTech Europe, Rijeka, Croatia. https://www.intechopen.com/books/soybean-molecularaspects-of-breeding/
Saxton, A. M. 1998. A macro for converting mean separation output to letter groupings in Proc Mixed. Pages 1243-1246 in: Proc. 23rd SAS Users Group Int. Conf. SAS Institute, Cary, NC.

Schlub, R. L., and Lockwood, J. L. 1981. Etiology and epidemiology of seedling rot of soybean by Pythium ultimum. Phytopathology 71:134-138.

Shurtleff, W., and Aoyagi, A. 2010. History of Soybeans and Soyfoods in Canada (1831-2010): Extensively Annotated Bibliography and Sourcebook. Soyinfo Center, Lafayette, CA.

Shurtleff, W., and Aoyagi, A. 2015. History of Soybeans and Soyfoods in Sweden, Norway, Denmark and Finland (1737-2015): Extensively annotated bibliography and sourcebook. Soyinfo Center, Lafayette, CA. (Online at www.soyinfocenter. com).

Shurtleff, W., and Aoyagi, A. 2017. Page 90 in: William Joseph Morse-History of His Work with Soybeans and Soyfoods (1884-2017). Soyinfo Center, Lafayette, CA

Urrea, K., Rube, J., Chen, P., and Rothrock, C. S. 2017. Characterization of seed rot resistance to Pythium aphanidermatum in soybean. Crop Sci. 57:13941403.

van der Plaats-Niterink, J. 1981. Monograph of the genus Pythium. Stud. Mycol. 21:1-244

van West, P., Appiah, A. A., and Gow, N. A. R. 2003. Advances in research on oomycete root pathogens. Physiol. Mol. Plant Pathol. 62:99-113.

Voldeng, H. D., Cober, E. R., Hume, D. J., Gillard, C., and Morrison, M. J. 1997. Fifty-eight years of genetic improvement of short-season soybean cultivars in Canada. Crop Sci. 37:428-431.

Voldeng, H. D., Seitzer, J. F., and Hamilton, R. I. 1985. Maple Isle soybean. Can. J. Plant Sci. 65:777-779.

Wang, Y., Hobbs, H. A., Hill, C. B., Domier, L. L., Hartman, G. L., and Nelson, R. L. 2005. Evaluation of ancestral lines of U.S. soybean cultivars for resistance to four soybean viruses. Crop Sci. 45:639-644.

Zhang, B. Q., and Yang, X. B. 2000. Pathogenicity of Pythium populations from corn-soybean rotation fields. Plant Dis. 84:94-99.

Zitnick-Anderson, K. K., and Nelson, B. D., Jr. 2015. Identification and pathogenicity of Pythium on soybean in North Dakota. Plant Dis. 99:31-38. 